\title{
The Evolution of the Concept of Public Diplomacy from the Perspective of Communication Stakeholders
}

\author{
Hasan Saliu*
}

\section{SUMMARY}

The purpose of this article was to analyse the concept of public diplomacy from the perspective of communication actors. Public diplomacy implies the communication between state and non-state actors and the foreign public, and the process of informing, influencing, establishing long-term relations and realizing foreign policy goals. While most studies to date view such communication activities as social interactions, some scholars consider them to be foreign policy activities, in which case the concept of public diplomacy is explained in terms of an interdisciplinary approach. Through the critical literature review, this article argues that public diplomacy shows the interaction between different communication stakeholders and the foreign public, where the former give direct messages and often achieve the desired effects through communication channels. By analysing public diplomacy activities carried out by communication actors, the article concludes that the concept of public diplomacy is clearly defined and more structured in communication sciences.

Keywords: public diplomacy, media, communication actors, foreign audience, information.

* Hasan Saliu, Prof. Asst. Dr., Faculty of Mass Communication, AAB College, Pristina, Kosovo, https://orcid.org/0000-0002-5864-3645,

Email: hasan.saliu@aab-edu.net 


\section{Introduction}

The promotion of the international image of a country is a critical dimension if the aim of any given government is to enhance the economic, political, cultural and ideological interests. Many countries have intensified their communication activities by organizing publicity campaigns including programs that range from cultural and touristic agendas to development work and aid programs. In today's globalized world, most countries are trying to attract international attention and gain a worldwide reputation (Skoko, Jakopović, Gluvačević, 2018). Through communication activities, these countries aim to reach an audience as wide as possible and create a positive impression of its national image for the foreign publics. The purpose of such communication activities is to achieve certain political, economic, and cultural objectives. Through such communication, state and non-state stakeholders seek either political alliances to achieve foreign policy goals, or trade and touristic benefits, increased investment, cultural benefits and the spread of their values. The discipline that brings together all these activities is public diplomacy, which implies communication between international actors (whether state or non-state stakeholders) and the foreign publics in order to promote foreign policy, typically informing, influencing, and raising the international image of an actor or an issue.

The international image of a country as perceived by foreign societies brings a significant impact on how the country can realize its foreign policy. Recent trends show that mainly the government of any given country seeks to present the country as a tourist destination while promoting its economic and cultural brands, or promoting them as desirable destinations not only for holidays but also for life, education and work (Skoko \& Gluvačević, 2016). Indeed, some scholars argue that a country image often brings in greater benefits than possessing a certain territorial area or raw material traditionally acquired through military and economic measures (Gilboa, 2008: 56). Defining the image of a country as various visions of foreign citizens for our country, rated with different qualifications and attributes, its shaping - either positive or negative - is a highly complicated and long-term process that encompasses a broad range of various communication sources and interacting stakeholders (Saliu, 2017a). Leonard (2002), a well-known practitioner of public diplomacy, emphasizes public diplomacy measures, which, through the image, bring benefits to the citizens of a country. In his view, public diplomacy is based on the premise that a country's image and reputation depend on public goods which can create a positive or negative environment for individual interests. (Leonard, 2002: 9). On the other hand, Castells (2010) considers the features of different countries more as an imaginary perception and according to him, such a perception is created through the means of mass communication. 
What these studies have in common is that the concept of public diplomacy is regarded primarily as a conglomeration of interdisciplinary activities often placed within, and between the fields of diplomacy, foreign policy, cultural studies, and even communication. This article seeks to situate public diplomacy within the comprehensive scope of communication with specific focus on communication stakeholders.

\section{The Evolution of the Term}

In its contemporary meaning, the term public diplomacy was first coined in 1965 by Edmund Gullion, Dean of the Fletcher School of Law and Diplomacy, in part to distance the activity of information governed by the term propaganda, which had acquired a negative connotation (Seib, 2009; Pamment, 2013; Cull, 2009a). Gullion, at that time, defined public diplomacy as follows:

...I [...] influence of public attitudes on the formation and execution of foreign policies. It encompasses dimensions of international relations beyond traditional diplomacy; the cultivation by governments of public opinion in other countries; the interaction of private groups and interests in one country with those of another; the reporting of foreign affairs and its impact on policy; communication between those whose job is communication, as between diplomats and foreign correspondents; and the processes of intercultural communications. (Quoted in Cull 2006).

Schindler (2018) points out that the first US public diplomacy mission began about 200 years ago when the Connecticut American Board of Commissioners for Foreign Missions sent two missionaries to Izmir in the Ottoman Empire.

Pliny Fisk and Levi Parsons volunteered to be the first missionaries to travel to the Ottoman Empire, arriving in Smyrna (Izmir) in 1819. For the first year or so, they were instructed to travel throughout the Empire, gathering information about the people and the environment and to learn languages before beginning any specific mission work ... The missionaries' role in the region circa 1820 1830 is significant to the story and origins of American public diplomacy. (Schindler, 2018: vii-x).

Prior to this reformulation, the term public diplomacy was first used in a different context with a different meaning by the London Times in January 1856; it was used as a synonym for public criticism of the pomposity of President Franklin Pierce (Cull, 2009b: 19). Later, the term public diplomacy is encountered for the first time used in the US, in the New York Times in 1871 reporting on a debate in the US Congress. Congressman Samuel S. Cox, a Democrat from New York and former jour- 
nalist who when criticizing the covert plants for the annexation of the Dominican Republic, said he believed in open public diplomacy (Cull, 2009b). Subsequently, on 11 February 1918, the term resurfaces in President Wilson's address to the Congress on his 'Four Principles'. Recounting his response to the German Chancellor Georg von Hertling on his Fourteen Points, he: [...] admitted [...] the principle of public diplomacy (Cull, 2009b: 20). In 1928, the term reoccurs in the newspaper Christian Science Monitor in the context of initiating a new era of public diplomacy and when analysing that international reporting should contain more moral in order to alleviate tension (Cull, 2009b). In 1936, a correspondent from Paris for the Associated Press wrote that the leftists had welcomed the position of the French Prime Minister Sarraut Albert to use public diplomacy in foreign affairs (Cull, 2009b).

While the term was rarely used during World War II, right after the War, in October 1946, the Belgian Foreign Affairs Minister Paul-Henri Spaak spoke with enthusiasm at the inaugural session of the UN General Assembly about these times of public diplomacy (Cull, 2009b). In 1953, Lippman (1998) defended another stance, writing that practices of public diplomacy, propaganda, and psychological war had become like the plague and that the main Soviet-American talks had to be kept private. He deemed on a more positive note the notion of public diplomacy from the UN Secretary-General Dag Hammarskjold, who, speaking in the summer of 1958, emphasized that the value of public diplomacy at the United Nations would depend on a decisive scale on the responsibility of spokespersons to speak about the international political life (Cull, 2009b). In other words, over the years, public diplomacy has detached itself from public affairs by referring more to domestic political activities and programs aimed at communicating and conveying messages to the internal audience.

In the United States, modern American diplomacy began during World War I, when the US government established the Public Information Committee (also known as the Creel Committee) to build support for the US-led war in the world. to inform and influence foreign opinion about US foreign policy efforts to support democracy and end the war (Laureano, 2006: 21). Many authors start with the Declaration of Independence (Pilon, 2008, Schlinler, 2018). According to Schindler (2018), the principles and ideas, such as freedom and the sovereignty of the public, are assumed to be universally acceptable and desired. 'America's evolving view of its relationship with the world and the principles which define American political culture impact the development and role of public diplomacy' (Schindler, 2018: 14).

The development of modern American public diplomacy experienced a rapid increase with the development of mass communication technology, i.e.: the cinema, radio, and television. Such progress was particularly notable after World War II (1940-1945) and after the Cold War (1991). At such times, academic articles on 
communication, media, and public opinion increased. For the American Government, the key efforts to influence foreign opinion and public diplomacy were exerted by the Office of War Information of the United States Information Agency (USIA). Since 1999, when USIA was transformed, this role was played by the State Department (Laureano, 2009: 21).

Meanwhile, the collapse of the Soviet Union (1991) and, in particular, the September 11 attacks on American soil in 2001, expanded the dimension of public diplomacy, bringing to the public and in all institutions, public and private operators who must be well informed for changes in technology, society and the political world. This requires new technology, ideas, paradigms and perhaps new institutions (Laureano, 2009: 7).

\section{The Government as a Communication Stakeholder}

It can be stated that public diplomacy concerns the communication of state and nonstate stakeholders, non-governmental organisations, corporates, individuals, etc., with foreign publics for the purpose of informing, influencing, and engaging them to achieve certain political and economic objectives of the country (Melissen 2005, Gilboa, 2008, Cull, 2012, Fisher, 2013). According to Tuch (1990), public diplomacy is a 'government's process of communicating with foreign publics in an attempt to bring about understanding for its nation's ideas and ideals, its institutions, and culture, as well as its national goals and policies' (p. 3). To achieve such objectives, communication with foreign publics is employed through various means, including international media, 'cultivating' international journalists and scholars, cultural activities, education exchanges and student scholarships, programmed visits and conferences, publications, etc. (Potter, 2007).

Despite the aforementioned definitions, the problem encountered in public diplomacy is the formulation of an agreed definition that would generally be accepted by all scholars. Public diplomacy has been defined several times by various scholars and practitioners of this field. Yet, thus far, it is not possible to provide a solid definition that would encompass the broad range of interests and practices corresponding to the given term (Pamment, 2013: 6). Edmund Gullion, former director of the Centre for Public Diplomacy 'Murrow' at Tufts University, who crafted the notion in 1966, defines public diplomacy as an activity that seeks to influence positions, shape and execute foreign policy (Pamment, 2013). According to him, public diplomacy involves the tools through which governments, private groups and individuals, influence the positions and opinions of other people and governments in order to exert their influence on their foreign policy decisions. Previous definitions by scholars and practitioners of public diplomacy included mainly the communication of the 
government with foreign opinions. Traditionally, public diplomacy concerns the communication of the government targeting foreign audiences to achieve changes in the hearts and minds of people (Szondi, 2008: 6). This interpretation historically took the form of contact between one government and the people of another state (Cull, 2009a: 12). Initially, it was not intended for a broad public but for individuals or limited groups of people conducted mainly through media as channels of communication. The media here appear often as the third communication stakeholder and not merely as an intermediary channel. In this framework, public diplomacy is based on the complicated relationship between three larger components: the government, the media, and the public opinion. Studies so far have yielded results in the research on the relationship between the media and public opinion or between the media and the government, but there are few studies connecting the three together (Gilboa, 2008). Between the 1970s and 1980s, an added interest in public diplomacy was the US government's attempt to spread as much information as possible to as many countries and audiences as possible in order to get the public's attention (Glassgold, 2004).

Overall, definitions provided by scholars of public diplomacy mainly focused on the overall goals that such communication activities seek to achieve, as well as the tools implemented at arriving such goals. Alongside these definitions, this paper stresses the limitations of the communication stakeholders. Furthermore, these definitions have presented the governments mainly as the primary communication stakeholders, as conveyors of the messages whereas the foreign audiences appear as recipients of these messages, and the media as the intermediary channel for communication. The ability for interaction between senders and receivers of the message here is quite limited and, in this case, the stakeholder of public diplomacy controls the message (Pamment, 2013). This also implies that by such definitions, only the governments appear to be the stakeholders of communication with foreign audiences.

In modern societies, this definition has become increasingly difficult to uphold. Namely, through technological development and globalization, the tripartite division between the government, media and people is increasingly undermined as the government's monopoly on media channels is carried over to the people, and individuals of society. This is discussed in more depth below.

\section{Governments and Individuals as Communication Stakeholders}

Apart from the government, non-state actors of a country appear as communication stakeholders, e.g.: various non-governmental organisations, international organisations, corporates, etc. These entities are either independent or in collaboration with the state. In 1968, Lee assessed that we live in the era of public diplomacy, where 
dialogue with one another is more important than communication between governments (Glassgold, 2004). In other words, Lee focused on foreign publics instead of the traditional diplomacy that pursued inter-governmental communication. This appeal for communication with 'one- another' would later add on communication stakeholders to include individuals from various countries, beyond the communication between state officials. Malone (1985) who was one of the USIA heads (197484), described public diplomacy in 1985 as the direct communication with foreign publics in order to influence their opinions, and ultimately, their governments. In fact, he believed strongly in the role of the state to manage and influence foreign publics through organized ways. His particularity lay in the inclusion of the private in the communication with foreign publics. In this sense, the Murrow Centre, in one of its brochures, described public diplomacy as follows:

Public diplomacy...deals with the influence of public attitudes on the formation and execution of foreign policies. It encompasses dimensions of international relations beyond traditional diplomacy; the cultivation by governments of public opinion in other countries; the interaction of private groups and interests in one country with another; the reporting of foreign affairs and its impact on policy; communication between those whose job is communication... (Cull, 2009b: 19).

Such descriptions are particularly important in our understanding of the term, as they introduced new communication stakeholders beyond the traditional governmental scope. While traditionally, scholars saw the state - and the state alone - as the stakeholder that communicates with foreign publics, here we see the emergence of private stakeholders and of other interest groups.

\section{From Information to Two-Way Communication}

In an attempt to engender an understanding of the national ideas and ideals of the government, its institutions and culture as well as its national objectives and current policy Tuch (1990), who is the author of the well-known work in this field 'Communicating with the World', defines public diplomacy as the governmental process of communicating with the foreign publics. According to him, public diplomacy seeks to communicate directly with people in other countries. He emphasizes that through such attempts, public diplomacy encompasses the entire spectrum of communication including various methods of intercultural communication, such as cultural and education exchanges, libraries, publications, professional and study exchanges, and training of foreign officials (Tuch, 1990: 4). According to him, this includes the experience of our learning, as we should understand the hopes, fears of other people should we wish to succeed in convincing them to understand us. 
According to the definitions of Tuch (1990), we can determine two dimensions of communication: the direct one, and the intervening dimension through media. This definition has two-fold importance: it increases the number of communication stakeholders of different professional backgrounds and seeks two-way communication not only to inform and convince foreign peoples where they are, through governmental and non-governmental messages using the media but also through direct exchange, through those who come to the country where such influencing messages are being disseminated. Although it increases the number of communication stakeholders, Tuch makes space only for the state, which should organize the other stakeholders from various professional profiles to communicate with the world.

Later on, the state's role declines when it becomes visible when various scholars see that non-state stakeholders come to the international scene including supranational organisations, regional or non-governmental organisations. Supranational and subnational stakeholders too, develop their policies of public diplomacy. For instance, with Kofi Annan in the media, the UN demonstrated supranational public diplomacy in action, and with Barroso, the European Commission gave primary priority to the EU public communication strategy (Melissen, 2005: 11). Thus, in the modern era of interdependence, the traditional function of the state is reduced to sub-systems (Diodato, 2003: 57). These sub-systems are seen as education systems, intercultural communication, etc.

The education exchange of different visitors, of cultural diplomacy, etc., as measures of public diplomacy, have opened up a new dimension, namely that of interhuman exchange, which conversely increased the number of communication stakeholders. This is another development of public diplomacy that has intensified person-to-person exchanges, either virtually or physically in person, across borders (Snow \& Taylor, 2009: 6). Here, as communication stakeholders with the foreign publics we have the individual, and individuals of two different countries communicate directly, without any channels of communication. This concerns various education programs, study scholarships, visits organised by representatives of various sectors, etc. Collaboration with non-governmental organisations in the host country, with the civil society and the use of leaders of local networks, increases the chances for building bridges of communication and cooperation (Riordan, 2005).

\section{Current Understanding of Public Diplomacy in the Age of Global Communication}

Nowadays, various non-state actors communicate with foreign individuals or peoples without the need for foreign exchange programs or visits. This is due to the development of communication technology, which enables real-time contacts be- 
tween people from different parts of the world while they remain in their own countries. In this respect, Cull (2012) defines public diplomacy as an effort of international stakeholders to lead foreign policy while dealing with other international stakeholders (p. x). He does not mention the many actors who take part in the Internet age, while others place emphasis on new media and new channels of communication. While face-to-face contacts in the society are limited, the Internet enables such contacts without the need to move physically from one place to another and results in saving time. Social media may play an important role in almost any country if they are developed and cultivated appropriately (Kiehl, 2012: 6). Pamment (2013) mentions in this regard the importance of social media in public diplomacy. In line with Wolton (2008), who argues for directing the exchange of the message between communication stakeholders, although fails explicitly deal with public diplomacy, Pammet (2013) emphasizes the inclusion of social media in public diplomacy when he notes that the internet appears as a deflection from the model of broadcasters and gives priority to the social media to decide on two-way interconnection with the public (Pamment, 2013: 3).

Nowadays, by public diplomacy, we mean the instrument used by the states, associations of the states, and some non-state stakeholders to understand the culture, positions, and behaviours; to establish and manage relations; to influence opinions and mobilize actions that steer forward their interests and values (Gregory, 2011). Metaphorically, this definition is about the democratisation of public diplomacy nowadays (Melissen, 2011: 2). The governmental communication, globalisation and emergence of new media pose a new challenge to the traditional ministry of foreign affairs, entities and organised structure. Pamment (2013) emphasizes that the new public diplomacy becomes the larger paradigm in the changes of the international political communication; from the old public diplomacy of the $20^{\text {th }}$ century, when we had the one-way communication into the new two-way diplomacy of the $21^{\text {st }}$ century (p. 3). Borders have become permeable as the recent technological advances have allowed for more stakeholders to partake in communication... adding to the debate, the new public diplomacy becomes a dialogue, becomes collaborative and inclusive (Pamment, 2013: 3).

Regarding collaboration and inclusion, the term collaborative public diplomacy is a relatively new interest that focuses on working with others, accepting their ideas and working with their ideas in combination with your ideas. According to Fisher (2013), collaborative public diplomacy should clearly guide the collaborative environment and paths, at a time when the difference between collaboration and improvisation is increasingly unclear (p. 28). One should identify the interest of the community, whereas the public diplomat should act specifically within the preferred environment of the community. This would increase the understanding with the community and interaction with the opinion. Pamment (2013) too speaks about the 
influence that may be achieved over the foreign peoples through public dialogue and collaboration. According to this perspective, public diplomacy is about dialogue, it is collaborative and inclusive (Pamment, 2013: 3). However, in spite of what is said 'should be' the era of networking, online communication, the inability of state stakeholder to massage the message that is directed to the foreign peoples, the states are increasingly losing ground from being communicating stakeholders with the foreign peoples and are managing information directed to the foreign peoples. More and more non-state actors and individuals are communicating from one corner of the world to another, completely independent. This Global Mass Publics (Pacher, 2018) and the advent of new information and communication technologies have brought the traditional conduct of public diplomacy in the face of essential challenges in the distribution of authorities across various fields. All such developments provide an opportunity to redefine public diplomacy in the conditions of an active role for the public, instead of passive objectives of governmental strategies for the foreign policy (Melissen, 2005: 30). Today, international communication is realized by representatives of foreign services, but also by representatives of other ministries, multinational corporations, civil society organizations, and even influential individuals who do not represent a particular state, organization, or corporation (Bjola and Kornprobst, 2018 p. 4).

The explosion of information through the internet increases the need for the credibility of such information. While the democratisation of foreign policy has increased, the transparency of foreign policy while at the same time mitigating the opportunities of attempts at manipulation (Potter, 2007: 21-23). Furthermore, the impact of digital technologies on diplomatic practice is codependent on our understanding of their nature when applied to social and political contexts (Melissen, 2017). Wolton (2009) says the Internet is an ocean of information, where online ghettoes of communication are created, within which various messages may be disseminated. Resultantly, online impatience, individualism, and extremism in today's virtual world have compelled a recent problem. Namely, the issue pertains to how communication between these ghettoes can be enhanced as they comprise of people with individual preferences rather than collective interests (Saliu, 2017b). This 'new' kind of public diplomacy engages in dialogue and establishes relationships with target audiences (Sevin, 2017: 32). Today's challenge relates to how governments select their public diplomacy targets (Pacher, 2018). This target audience does not just mean that public diplomacy campaigns should be directed towards the public and countries that the country has more interest and not global campaigns, but also within the public of a country, the target should be identified. In other words, the public must be separated from the age, gender, and professional profiles for a country, so that the message, the communication channel, and the nature of the interaction are more tempting. This is also stated in Leonard (2002): "The challenge 
is to understand the concerns of the targeted audience and build on areas of mutuality" (p. 52). Another challenge is for diplomats to know how to use the latest technological applications and to be constantly active in new technologies not only to attract attention, but also to critique and comprehend the digital realm (Melissen, Keulenaar, 2017: 7).

\section{Situation with Public Diplomacy Studies}

In the last thirty years, public diplomacy has become the subject of inquiry among academics, current and former practitioners, government research bodies, and independent think tanks (Schindler, 2018: 3). Public diplomacy has become a term that is encountered widely in the circles of scholars and practitioners of traditional diplomacy (Jönsson \& Hall, 2005). Additionally, it has become the most debatable topic in the realms of international communication (Taylor, 2009: 12). Different countries, be they democratic or authoritarian regimes; affluent like Norway or poor like Ethiopia, have indicated a great interest in public diplomacy (Melissen, 2005: 8). This field comprises the communication of nation-state and non-state stakeholders - by citizens of foreign countries. This stakeholder may be a representative of civil society, of a non-governmental or multi-national organisation, a journalist or a medium, a specialist of various industry sectors, of politics, or member of a constituency (Pamment, 2013: 1).

Studies of public diplomacy focus on two main aspects: the theoretical interpretations and the content of activities in practice. In other words, public diplomacy is a new field of practice and knowledge (Gilboa, 2008). Its first plane, that of theoretical interpretation, seeks to explain basic concepts of what is meant by public - or mass-diplomacy; what is the explanatory theory for such communication with the foreign publics and the relationship between this field and other fields of communication. Its second plane that of activity description, incorporates the measures that are undertaken in this field, to realize communication with the foreign publics. Such measures incorporate three dimensions of the public diplomacy: management of information that is generated on daily basis and primarily through media and internet, which are used as channels of communication to convey as many messages to the foreign peoples with the intention of informing, influencing and engaging them; the strategic communication represents the second dimension that has the same goal, and the third dimension - that of cultural diplomacy - which is realised without any intermediary or media channels, through student and culture exchange, tourism, diaspora etc. (Tuch, 1990; Nye, 2004; Melissen, 2005; Szondi, 2008; Cull, 2009a, Pamment, 2013, 2016).

However, studies on public diplomacy were scarce until the beginning of this decade. There is but a small number of monographs dedicated to public diplomacy and 
only some articles tackle its theoretical issues. The majority of publications were a summary of papers edited by scholars of international communication or public diplomacy. Most were historical and focus on activities of public diplomacy of different countries, the US, and UK in particular. In addition to the Anglo-Saxon countries and with the exception of a few articles on French audio-visual policy or German cultural policy, we are almost silent on the subject of public diplomacy (Pahlavi, 2004: 31). English-language literature on public diplomacy is relatively limited, and research is based on what we have; while there is no considerable literary body in languages other than English, i.e. French or German (Brown, 2012: 2). In 19922003, there were less than 30 books by academic researchers with public diplomacy as a central theme, and such a number is ridiculous (Pahlavi, 2004: 31). According to Gilboa (2008), existing research in public diplomacy suffers from a range of serious deficiencies, while previous publications from the Cold War era are largely historical and their contribution to the development of public diplomacy theory and methodology has been limited. (p. 56). According to one of the most-cited European scholar Melissen (2005), after the Cold War, there is a very small body of scientific literature on public diplomacy (p. xix). Those dealing with this area mainly encounter a large number of journal articles that tackle public diplomacy in their own way, more often using rather than delving into studies in the field, while elaborating indepth the political analysis, comments and quick advices from different policymakers in different countries of the world; often confusing public diplomacy with the traditional one.

Even after 11 September 2001, many governments, public agencies, and organisations have published a series of reports, most repeating the challenges, ideas, and principles. These reports have also failed to sufficiently contribute to advancing the theory and methodology of public diplomacy. In the last decade, the number of scientific articles published in communications and diplomacy journals has significantly increased, particularly in Place Branding and Public Diplomacy journal (https://www.palgrave.com/gp/journal/41254) by Anholt (2007), who has given life to the concept of nation branding - a concept that competes with that of public diplomacy, which, however, refers to competition between one country with other countries in the global market (p. 1). Other significant contributors with reports and articles on public diplomacy are the USC Centre on Public Diplomacy (https://uscpublicdiplomacy.org/) and the Dutch Institute Clingendael (https://www.clingendael. org). Several authors of publications base their key references to definitions and taxonomies from the publication of Tuch (1990), whereas Leonard (2002) remains an authority on public diplomacy activities, who at the same time is the only practical monographer in this field on the European scene. The European author Melissen (2005), the American Cull (2009a, 2009b, 2012), and the Israeli Gilboa (2008) are the most cited authors with regards to theoretical explanations of public diplomacy. 
However, Nye (2004) with his concept of soft power - the attractive power of a country - also remains much-cited, a concept that encompasses public diplomacy but nevertheless, soft power is not the object of this article. The summaries of the studies mainly concern different countries and sectors of public diplomacy (Melissen, 2005; Seib, 2009; Kiehl, 2012, Snow \& Taylor, 2009; Lee \& Melissen, 2011; Cull, 2012; Pamment, 2013; Zaharna et al. 2013). Articles about American diplomacy prevail; followed by those on some European and Asian countries, and sectorspecific topics such as cultural diplomacy, exchanges, efforts to provide theoretical explanations in the field, etc.

However, in the last five years, an expansion of public diplomacy studies can be witnessed in different countries. Today, dozens of studies, edited books, and hundreds of articles have extended the scope of public diplomacy from the US and Britain to other European contexts including Germany, France, Spain, Denmark, Norway, Turkey and so on. The eastern context of China, Korea, India (ex. Melissen \& Sohn, 2015; Hartig, 2016; d'Hooghe, 2015, Kadir, 2017), but also Singapore has also been examined in the perspective of soft power studies and public diplomacy. Most recently, studies of public diplomacy have reached global interest in Canada, Japan (eg, Brooks, 2019), Russia (ex. Simons, 2018, 2014) as well as Brazil (Chatin, 2016), and countries in the African continent including Nigeria, and Algeria (ex. Chity, Ji, Rawnsley, Hayden, 2017).

\section{Conclusion}

Public diplomacy can be entirely structured within the scope of communication sciences. Initially, state actors sent elaborated messages to foreign audiences, and this communication can be said to be manageable by the state. The message in this phase has only one way. This sending of one-way information without any possibility for dialogue or feedback is also employed with the foreign peoples is closely connected or co-existing concepts to public diplomacy such as propaganda, national trademark etc. For this reason, too, the concept of public diplomacy was often seen as a euphemism for propaganda. Governments crafted messages addressed to foreign peoples through media as an intermediary channel with the sole purpose of informing and influencing them. Such measures cannot be removed from propaganda unless other communication stakeholders are involved. Over time, the inclusion of non-state stakeholders in communication and the loss of the governments' monopoly over mass communication with foreign publics resulted in public diplomacy detaching itself from merely conveying influential messages. This marked yet another dimension of directing messages: from information by state stakeholders as a one-way activity of disseminating messages to the foreign audiences towards a two-way exchange of messages. The mass communication of non-state stakeholders with the 
outside world resulted in the emergence of dialoguing between the individuals of different peoples. Initially, the individuals were exchanged in an organized way through visits, study scholarships, or cultural exchanges. In this case, we deal with the inability of the state to control the messages transmitted to the foreign audience. The process of such communication encompasses a series of activities undertaken not just through media but also through a series of other measures that intend to present a good image of a country. Dialoguing relationships between the publics involve certain activities, such as education exchanges for students and scholars, visiting programs, language training, cultural events and exchanges, radio-television programs and industry, conveying messages through media, etc. These activities usually focus on sending a positive image or reputation of a country over to the foreign peoples as a way to convey messages from the political, economic, cultural and touristic context.

Studies of diplomacy later noted the importance of people moving to other countries or arriving in countries that sought to create a positive image in other countries. Tourists, visitors, diaspora, communicate in a host country in a natural way, unaffected by the country of origin and completely independent. In this case, we can say that the concept of public diplomacy has evolved as a result of the inability of state actors to control the message addressed to foreign audiences. The Internet today has expanded this concept even further; and today everyone communicates with everyone in the world, without having any influence from others. Each individual has the choice of selecting the information to be received or the communication to be made, unlike the traditional mass media where the message imposed itself on the individuals without giving them a choice to refuse the selection of such information. This creates communication pockets or ghettoized communication groups who not only refuse to share information with other ghettos or communicate with them, but often, apart from quick virtual feedback, do not consider them important interlocutors for serious issues. The latter presents a challenge in the era of the globalized world, because the village of McLuhan already represents not only an information society in a network society of communication, media, but more.

\section{Declaration of Conflicting Interests}

The author declared no potential conflicts of interest with respect to the research, authorship, and/or publication of this article.

\section{Funding}

This research has received no specific grant from any funding agency in the public, commercial, or not-for-profit sectors. 
The Evolution of the Concept of Public Diplomacy...

\section{REFERENCES}

Anholt. S, (2007) Places, Identity, image and reputation. London: Palgrave Macmillan.

Ayhan, K. (2017) Korea‘s Soft Power and Public Diplomacy. Seul: Hangang Network.

Bjola, C. \& Kornprobst, M. (2018) Understanding International Diplomacy - Theory, Practice and Ethics (II Edit.). New York: Routledge.

Brooks, S. (Ed.) (2019) Promoting Canadian Studies Abroad-Soft Power and Cultural Diplomacy. Switzerland: Palgrave Macmillan.

Brown, R. (2012) The Four Paradigms of Public Diplomacy: Building a Framework for Comparative Government External Communications Research. University of Leeds: Institute of Communication Studies. April.

Castells, M. (2010) The power of Identity, The Information Age Economy, Society, and Culture (II Edit.). Wiley Blackwell.

Chatin, M. (2016) Brazil: analysis of a rising soft power. Journal of Political Power. https://doi.org/10.1080/2158379X.2016.1232286

Chitty, N. J. L., Rawnsley, G. D. \& Hayden, C. (Eds.) (2017) The Routledge Handbook of Soft Power. London and New York: Routledge.

Cull, N. J. (2012) The Decline and Fall of the United States Information Agency: American Public Diplomacy, 1989-2001. Palgrave Macmillan.

Cull, N. J. (2009a) Public Diplomacy: Lessons from the Past. Los Angeles: Figueroa Press, USC Center on Public Diplomacy. Retrieved from http://uscpublicdiplomacy.org/sites/uscpublicdiplomacy.org/files/useruploads/u35361/2009\%20 Paper\%202.pdf

Cull, N. J. (2009b) Public Diplomacy before Gullion-The Evolution of a Phrase. in: Nancy Snow \& Philip M. Taylor (Eds.), Routledge Handbook of Public Diplomacy. New York-London: Routledge.

Cull, N. J. (2006) Public Diplomacy Before Gullion: The Evolution of a Phrase. USC Center on Public Diplomacy Blog, April 18. https://uscpublicdiplomacy. org/blog/public-diplomacy-gullion-evolution-phrase

D'Hooghe, I. (2015) China's Public Diplomacy. Leiden-Boston: Brill Nijhoff.

Diodato, E. (2003) Introduzione alla comunicazione politica internacionale. Perugia: Guerra Edizioni.

Gilboa, E. (2008) Searching for a Theory of Public Diplomacy. The Annals of the American Academy of Political and Social Science. Sage. March. https://doi. org $/ 10.1177 / 0002716207312142$

Fisher, A. (2013) Collaborative Public Diplomacy, How Transnational Networks Influenced American Studies in Europe. Palgrave MacMillan. 
Medij. istraž. (god. 26, br. 1) 2020. (69-86)

Glassgold, S. M. (2004) Public Diplomacy - The Evolution of Literature. US Center on Public Diplomacy. Retrieved from http://uscpublicdiplomacy.org/pdfs/ Stacy_Literature.pdf.

Gregory, B. (2011) American Public Diplomacy: Enduring Characteristics, Elusive Transformation. The Hague Journal of Diplomacy, Volume 6, Issue 3-4. https:// doi.org/10.1163/187119111X583941

Hartig, F. (2016) Chinese Public Diplomacy. New York: Rootledge.

Jönsson, Ch. \& Hall, M. (2005) Essence of Diplomacy. New York: Palgrave Macmillan.

Kiehl, W. P. (2012) The Last Three Feet: Case Studies in Public Diplomacy (Eds.) Washington: Public Diplomacy Councill.

Laureano: (2006) Fondamenti di communicazione politica internazionale. Roma: Bonanno Editore.

Lee, S. J. \& Melissen, J. (Eds.) (2011) Public diplomacy and soft power in East Asia. New York: Palgrave Macmillan.

Leonard, M. (2002) Public Diplomacy. London: The Foreign Policy Centre.

Lippman, W. (1998) Pubblic Opinion. New Brunswick (U.S.A.) and London (U.K.): Transaction Publishers.

Malone, G. D. (1985) Managing public diplomacy. Washington Quarterly 8 (3) https://doi.org/10.1080/01636608509450301

Melissen, J. (2005) The New Public Diplomacy: Between Theory and Practice. In: J. Melissen (Eds.), New public diplomacy: soft power in international relations (pp. 3-27) New York: Palgrave Macmillan.

Melissen, J. (2011) Beyond the New Public Diplomacy. Netherlands Institute of International Relations, Clingendael. Retrieved from: https://www.clingendael. org/sites/default/files/pdfs/20111014_cdsp_paper_jmelissen.pdf

Melissen, J. \& Sohn, Y. (2015) Understanding Public Diplomacy in East Asia Middle Powers in a Troubled Region (Eds) New York: Palgrave Macmillan.

Melissen, J. \& De Keulenaar, E. V. (2017) Critical Digital Diplomacy as a Global Challenge: The South Korean Experience. Global Policy. https://oi.org/ 10.1111/1758-5899.12425

Nye, J. Jr. (2004) Soft power: The means to success in world politics. New York: Public Affairs.

Pacher, A. (2018) Strategic Publics in Public Diplomacy: A Typology and a Heuristic Device for Multiple Publics. The Hague Journal of Diplomacy. https://doi. org/10.1163/1871191X-13020004

Pahlavi, C. T. (2004) Mass Diplomacy: Foreign Policy in the Global Information Age. Montreal: McGiII University. 
Pamment, J. (2013) New Public Diplomacy in the 21st Century: A Comparative Study of Policy and Practice. London-New York: Routledge.

Pamment, J. (2016) British Public Diplomacy and Soft Power: Diplomatic Influence and the Digital Revolution. Palgrave Macmillan.

Pilon, J. G. (2008) American Exceptionalism: Implications for Strategic Communication. Israel Journal of Foreign Affairs, Vol. 2: 129-140. https://doi.org/10.108 $0 / 23739770.2008 .11446337$

Potter, E. H. (2007) Canada and the New Public Diplomacy. Netherlands Institute of International Relations 'Clingendael'. April. Retrieved from https://www.clingendael.org/sites/default/files/pdfs/20020700_cli_paper_dip_issue81.pdf

Riordan, Sh. (2005) Dialogue-based Public Diplomacy: New Foreign Policy Paradigm? In: J. Melissen, New public diplomacy: soft power in international relations (Eds.) Palgrave Macmillan.

Saliu, H. (2007a) International image of the country through strategic communication, Case of Kosovo. Journal of Media Critiques. https://doi.org/10.17349/ jmc117105

Saliu, H. (2007b) The new nature of Cultural Diplomacy in the age of online communication. Journal of Media Critiques. https://doi.org/10.17349/jmc117206

Seib, Ph. (Ed.) (2009) Toward a New Public Diplomacy - Redirecting U.S. Foreign Policy. Palgrave Macmillan.

Sevin, E. (2017) Public Diplomacy and the Implementation of Foreign Policy in the US, Sweden and Turkey. Switzerland: Palgrave Macmillan.

Simons, G. (2018) The Role of Russian NGOs in New Public Diplomacy. Journal of Political Marketing. 137-160. https://doi.org/10.1080/15377857.2018.1447755

Simons, G. (2014) Russian public diplomacy in the 21st century: Structure, means and message. Public Relation Review. 440-449. https://doi.org/10.1016/j.pubrev.2014.03.002

Skoko, B. \& Gluvačević, D. (2016) Države kao turistički brendovi: kreiranje, upravljanje i vrednovanje. Medijske studije 7, br. 13 (2016): 78-100. https://doi. org/10.20901/ms.7.13.5

Skoko, B., Jakopović, H. \& Gluvačević, D. (2018) Challenges of branding in postconflict countries: The case of Bosnia and Herzegovina. Turizam 66, br. 4 (411427). Retrieved from https://hrcak.srce.hr/214038

Schindler, C. E. (2018) The Origins of Public Diplomacy in US Statecraft. Switzerland: Palgrave McMillan.

Snow, N. \& Taylor, Ph. M. (2009) Routledge Handbook of Public Diplomacy (Eds.). New York-London: Routledge.

Szondi, G. (2008) Public Diplomacy and Nation Branding: Conceptual Similarities and Differences. Netherlands Institute of International Relations 
Medij. istraž. (god. 26, br. 1) 2020. (69-86)

'Clingendael'. Retrieved from https:/www.clingendael.org/sites/default/files/ pdfs/20081022_pap_in_dip_nation_branding.pdf

Soroka, S. N. (2003) Media, Public Opinion, and Foreign Policy. International Journal of Press/Politics. https://doi.org/10.1177/1081180X02238783

Taylor, Ph. M. (2009) Public Diplomacy and Strategic Communications. In: N. Snow \& Ph. M. Taylor (Eds.), Routledge Handbook of Public Diplomacy (pp. 12-16). New York-London: Routledge.

Tuch, H. N. (1990) Communicating with the World: U. S. Public Diplomacy Overseas. Washington, DC: Georgetown University.

Wolton, D. (2009) Informer n'est pas communiquer. Paris: CNRS Editions.

Zaharna, R. S., Arsenault, A. \& Fisher, A. (Eds.) (2013) Relational, Networked and Collaborative Approaches to Public Diplomacy: The Connective Mind shift. New York: Routledge.

\section{Evolucija koncepta javne diplomacije iz perspektive aktera komunikacije}

\section{Hasan Saliu}

\section{SAŽETAK}

Svrha je ovog članka analizirati koncept javne diplomacije iz perspektive aktera komunikacije. Javna diplomacija podrazumijeva komunikaciju državnih i nedržavnih aktera sa stranom javnošću, informiranje, utjecaj, stvaranje dugoročnih odnosa kao i ostvarivanje vanjske politike. Dok većina studija do danas takve komunikacijske aktivnosti gleda kao društvene interakcije, neki znanstvenici smatraju ih aktivnostima vanjske politike, pri čemu se pojam javne diplomacije objašnjava interdisciplinarnim pristupom. Ovaj članak, kroz pregled literature, tvrdi da se javna diplomacija zapravo odnosi na interakciju između različitih dionika komunikacije i strane javnosti, gdje prve daju izravne poruke i često, putem kanala komunikacije, postižu željene efekte. Analizirajući aktivnosti javne diplomacije od strane aktera u komunikaciji, zaključuje se da je koncept javne diplomacije jasno definiran i najviše strukturiran unutar komunikacijskih znanosti.

Ključne riječi: javna diplomacija, mediji, akteri komunikacije, strana javnost, informacije. 